\title{
STRATEGI INTERNALISASI KARAKTER RELIGIUS PESERTA DIDIK DI SDIT QURROTA A'YUN ABEPURA KOTA JAYAPURA MELALUI ISLAMIC CULTURE
}

\author{
Poppy Pritasari Prasetya, Marwan Sileuw, Didik Efendi \\ IAIN Fattahul Muluk Papua \\ e-mail: poppyprasetya44@gmail.com, sileuwmarwan@gmail.com,didik.kotjap@gmail.com
}

\begin{abstract}
ABSTRAK
Lingkunagan plural akan mempengaruhi karakter seseorang terutama anak usia 6-12 tahun. Pendidikan karakter harus digalakkan mulai dari Pendidikan jenjang dasar. SDIT Qurrata A'yun merupakan salah satu sekolah dasar yang mempunyai visi membentuk akhlakul karimah kepada peserta didiknya. Pembudayaan nilai-nilai islami baik dalam pembelajaran maupun non pembelajaran di SDIT Qurrata A'yun terlihat efektif dalam mentranfer nilai-nila karakter terutama karakter religius. Disatu sisi SDIT Qurrata A'yun menggabungkan kurikulum 2013 dan kurikulum JSIT (Jaringan Sekolah Islam Terpadu). Penelitian ini menggunakan penelitian kualitatif deskriptif dengan teknik pengumpulan datanya melalui observasi partisipan, wawancara dan dokumentasi. Sedangkan Teknik analisis datanya menggunakan empat tahapan yakni Pengumpulan data, reduksi data, penyajian data dan penarikan kesimpulan. Hasil penelitian menunjukan bahwa dalam internalisasi karakter religius pada peserta didik di SDIT Qurrata A'yun melalui Islamic Culture mencangkup beberapa hal, yakni (1) pemberian contoh (keteladanan); (2) peniruan (imitasi); (3) pembiasaan; (4) praktik. Adapun faktor yang mendukung keberhasilan internalisasi karakter religius peserta didik di SDIT Qurrota A'yun Abepura Kota Jayapura diantaranya yaitu Lingkungan dan Partisipasi. Sedangkan faktor yang menghambat adalah dukungan sosial yang tidak kondusif dan karakteristik peserta didik.
\end{abstract}

Kata kunci : Internalisasi, Karakter Religius dan Islamic culture

\section{PENDAHULUAN}

Pendidikan karakter adalah salah satu pendidikan yang bertujuan untuk mencetak generasi Indonesia yang berakhlak mulia. Untuk itu pendidikan karakter harus diberikan kepada anak sedini mungkin, agar menjadi pondasi atau dasar dalam melakukan sesuatu. Salah satu faktor yang mempengaruhi karekter atau akhlak anak adalah lingkungan heterogen atau plural. Salah satu kota yang masyarakatnya plural adalah Kota Jayapura, karena Kota Jayapura terdapat berbagai suku, bahasa, agama, budaya dan perbedaan-perbedaan lainnya. Semakin banyaknya suku, budaya dan agama, maka semakin banyak pula karakteristik, budaya atau kebiasaan-kebiasaan yang beragam.

Dengan melihat fenomena diatas maka lembaga pendidikan harus mengambil andil dalam memberikan solusinya. Lembaga pendidikan harus membuat formulasi yang tepat guna menanamkan karakter atau akhlak kepada siswa-siswanya serta membuat strategi guna bersinergi dengan orang tua siswa maupun lembaga yang terkait dalam menangani permasalahan tersebut. Terdapat 18 nilai karakter yang dikembangkan dalam pendidikan karakter yang terdiri dari religius, jujur, toleransi, disiplin, kerja keras, kreatif, mandiri, demokrasi, rasa ingin tahu, semangat 
kebangsaan, cinta tanah air, menghargai prestasi, bersahabat atau komunikatif cinta damai, gemar membaca, peduli lingkungan, peduli sosial, dan tanggung jawab. Di antara nilai nilai karakter tersebut, masing-masing sekolah bebas memprioritaskan sekolah mana yang akan dikembangkan sesuai dengan karakteristik dan kebutuhan peserta didik dan lingkungan sekitar ${ }^{1}$.

Menurut Didik Efendi dalam penelitiannya mengatakan bahwa karkater bukan sesuatu yang diwariskan dari orang tua maupun keluarganya, tetapi karkarter harus dibentuk secara berkelanjutan dan berkesinambungan dari waktu ke waktu melalui pikiran dan perbuatan. Untuk itu nilai-nilai karakter perlu ditanamkan kepada anak sedini mungkin. ${ }^{2}$ Sekolah Dasar Islam Terpadu yang sering disebut dengan SDIT mempriotaskan pendidikan karakter menjadi salah satu program keunggulannya. Dalam penelitian ini, peneliti hanya mengkaji salah satu pendidikan karakter yang menonjol di SDIT Qurrata A'yun Kota Jayapura yakni karakter relegius. Hal ini sebabkan dalam observasi awal karakter-karakter relegius sangat tampak atau diimplentasikan dalam kegiatan pembelajaran maupun non pembelajaran, misalnya peserta didik diajak untuk mau memperingati hari-hari besar keagamaan dan kegiatan yang bernuansa Islam dalam sekolah tersebut yang kemungkinan besar juga memberikan sumbangan informasi kepada peserta didik tentang materimateri yang dipelajari di dalam kelas serta pembiasaan karakter religius pada peserta didik.

Selain itu, karakter religius yang ada di SDIT Qurrota A'yun Abepura yaitu menerapkan senyum, salam dan sapa terhadap siapa saja yang ditemui di sekolah, menerapkan sholat dhuha dan melafalkan asmaul husna sebelum memulai pelajaran, melaksanakan puasa senin kamis untuk peserta didik kelas 4 hingga 6, melaksanakan sholat dzuhur dan ashar berjama'ah, membiasakan peserta didik membaca do'a sebelum memulai pelajaran, do'a makan dan sesudah makan, do'a sebelum masuk kamar mandi dan keluar kamar mandi, do'a sebelum wudhu dan do'a setelah wudhu, muroja'ah bersama di lapangan, sehari berbicara bahasa arab, safari Qur'an, infak hari jum'at, mengaji metode ummi dan pelajaran tahfidz setiap hari, beristighfar jika melakukan kesalahan atau berbicara yang kurang sopan.

Berdasarkan uraian tersebut maka perlu adanya kajian yang mendalam terkait strategi internalisasi karakter relegius pada peserta didik SDIT Qurrota A’yun Abepura yang bertujuan untuk medeskripsikan strategi internalisasi karakter religius peserta didik di SDIT Qurrota A'yun Abepura Kota Jayapura melalui islamic culture dan mengetahui faktor pendukung dan faktor penghambat strategi internalisasi karakter religius peserta didik di SDIT Qurrota A'yun Abepura Kota Jayapura melalui islamic culture.

\footnotetext{
${ }^{1}$ Kemendiknas, Pedoman Pelaksanaan Pendidikan Karakter $\quad$ (Jakarta: Kemendiknas, 2011), hlm. 8.

2 Didik Efendi, "Strategi Penanaman Karakter pada Anak Usia Sekolah Dasar di Kota Jayapura," Jurnal Elementaria Edukasia, 4.1 2021, hlm. 2
} 


\section{METODE PENELITIAN}

Penelitian ini menggunakan rancangan penelitian kualitatif dengan metode penelitian deskriptif. Penelitian yang menghasilkan data deskriptif yang berupa kata-kata tertulis atau lisan dari orang-orang dan perilaku yang dapat diamati dengan tujuan untuk memaparkan dan menggambarkan dan memetakan fakta-fakta berdasarkan cara pandang atau kerangka berpikir tertentu. Penelitian dilakukan di SDIT Qurrata A'yun Abepura yang terletak di kota Jayapura Provinsi Papua dengan sampel guru dan peserta didik.

Adapun data yang digunakan adalah data primer dan sekunder dengan teknik pengumpulan datanya dengan (1) observasi partisipan yakni peneliti terlibat secara langsung dengan kegiatan sehari-hari orang yang sedang diamati atau digunakan sebagai sumber data penelitian. Sambil melakukan pengamatan, peneliti ikut melakukan apa yang dikerjakan oleh sumber data, dan ikut merasakan suka dukanya. Dengan observasi partisipan ini, maka data yang diperoleh akan lebih lengkap, tajam, dan sampai mengetahui pada tingkat makna dari setiap perilaku. (2) wawancara. yakni Wawancara adalah percakapan dengan maksud tertentu percakapan itu dilakukan oleh dua pihak, yaitu pewawancara yang mengajukan pertanyaan dan terwawancara yang memberikan jawaban atas pertanyaan yang diajukan. Adapun orang yang diwawancarai adalah guru dan peserta didik di lingkungan SDIT Qurrata ayun, (3) dokumentasi yakni mencari data mengenai hal-hal atau variabel yang berupa catatan transkip, buku, surat kabar, majalah, prasasti, notulen rapat, lengger, agenda, dan sebagainya. Melalui metode ini peneliti menggali data berdasarkan catatan-catatan atau dokumen lain yang dimiliki SDIT Qurrota A’yun Abepura Kota Jayapura.

Adapaun teknik analisis datanya menggunakan model Model analisis data yang digunakan dalam penelitian ini adalah model interaktif yang dikembangkan oleh Miles dan Huberman, yakni dimulai dengan pengumpulan data, reduksi data, penyajian data, dan penarikan kesimpulan/verifikasi. Proses analisis data dilakukan secara terus menerus di dalam proses pengumpulan data selama penelitian berlangsung.

1. Pengumpulan data, dalam tahap ini peneliti melakukan studi awal melalui dokumentasi dan observasi.

2. Reduksi Data: Yaitu merangkum data, memilih hal-hal yang pokok, memfokuskan pada hal-hal yang penting, dan membuang hal-hal yang tidak diperlukan.

3. Data Display (Penyajian Data): Yaitu membuat uraian singkat, bagan, hubungan antar kategori dan sejenisnya;

4. Conclusion Drawing/verification: Yaitu penarikan kesimpulan dan verifikasi 


\section{HASIL PENELITIAN DAN PEMBAHASAN}

Secara etimologi, istilah karakter berasal dari bahasa latin character, yang berarti watak, tabiat, sifat-sifat kejiwaan, budi pekerti, kepribadian dan akhlak. Dalam kamus besar bahasa indonesia sifat-sifat kejiwaan, akhlak atau budi pekerti yang membedakan seseorang dari yang lain; tabiat; watak. Secara terminologi (istilah), karakter diartikan sebagai sifat manusia pada umumnya yang bergantung pada faktor kehidupannya sendiri. Sedangkan Religius dapat dipahami sebagai nilai karakter dalam hubungannya dengan tuhan yang menunjukkan bahwa pikiran, perkataan dan tindakan seseorang yang diupayakan selalu berdasarkan pada nilai-nilai ketuhanan dan atau ajaran agamanya $^{3}$

Dalam Karakter religius terdapat nilai-nilai kehidupan yang mencerminkan tumbuh kembangnya kehidupan beragama yang terdiri dari tiga unsur pokok yaitu aqidah, ibadah, dan akhlak yang menjadi pedoman perilaku seseorang sesuai dengan aturan-aturan untuk mencapai kesejahteraan serta kebahagiaan hidup di dunia dan di akhirat. Menurut Muhammad Fathurrahman nilai-nilai religius terbagi sebagai berikut

1. Nilai Ibadah. Ibadah adalah ketaatan manusia kepada Tuhan yang diimplementasikan dalam kegiatan sehari-hari misalnya sholat, puasa, zakat, dan lain sebagainya,

2. Nilai Ruhul Jihad. Ruhul Jihad adalah jiwa yang mendorong manusia untuk bekerja atau berjuang dengan sungguh-sungguh,

3. Nilai Akhlak dan Disiplin Akhlak merupakan bentuk jama' dari khuluq, artinya perangai, tabiat, rasa malu, dan adat kebiasaan. Sedangkan kedisiplinan itu termanifestasi dalam kebiasaan manusia ketika melaksanakan ibadah rutin setiap hari. Semua agama mengajarkan suatu amalan yang dilakukan sebagai rutinitas penganutnya yang merupakan sarana hubungan antara manusia dengan pencipta-Nya.

4. Keteladanan. Nilai keteladanan ini tercermin dari perilaku guru. Keteladanan merupakan hal yang sangat penting dalam pendidikan dan pembelajaran.

5. Nilai Amanah dan Ikhlas. Amanah artinya dapat dipercaya, sedangkan ikhlas secara bahasa berarti bersih dari campuran hal kotor ${ }^{4}$.

Menurut Kemendiknas, ada 2 (dua) jenis indikator yang dikembangkan dalam pendidikan karakter di sekolah:

\footnotetext{
${ }^{3}$ Mohamad Mustari, Nilai Karakter Refleksi untuk Pendidikan (Jakarta: Rajawali Press, 2014), hlm. 1.

${ }^{4}$ Fathurrahman, Budaya Religius dalam Peningkatan Mutu Pendidikan, Tinjauan Teoritik dan Praktik Konstekstualisasi Pendidikan Agama di Sekolah (Yogyakarta: Kalimedia, 2015), hlm. 60-69.
} 
1. Indikator untuk sekolah dan kelas. Indikator sekolah dan kelas adalah penanda yang digunakan oleh kepala sekolah, guru, dan personalia sekolah dalam merancanakan, melaksanakan, dan mengevaluasi sekolah sebagai lembaga pelaksana pendidikan karakter. Indikator ini juga berkenaan dengan kegiatan sekolah yang diprogramkan, maupun kegiatan sehari-hari atau rutinitas sekolah.

2. Indikator mata pelajaran. Indikator ini menggambarkan perilaku afektif seorang peserta didik berkenaan dengan mata pelajaran tertentu. Indikator ini dirumuskan dalam bentuk perilaku peserta didik di kelas dan sekolah, yang dapat diamati melalui pengamatan guru ketika seorang peserta didik melakukan suatu tindakan di sekolah, tanya jawab dengan peserta didik.

Karakter tidak datang dengan sendirinya butuh beberapa waktu dan strategi khusus untuk membentuk karakter tersebut menjadi karakter permanen atau akhlakul karimah. Menurut Didik Efendi terbentuknya akhlak pada peserta didik usia sekolah dasar di Kota Jayapura terdapat empat tahap yakni (1) Receiving (menerima) : guru memberikan pemahaman tentang nilai-nila karakter yang akan ditanamkan melului pembelajaran ataupun keteladanan guru. (2) Responding (menanggapi). Dalam hal ini peserta didik akan merespon apa yang telah diperikan guru pada taham receivig. Peserta didika akan memberikan tahapan menolak atau menerima hal-hal yang telah diberikan guru. (3) Acting (bertindak). Dalam tahapan ini peserta didik akan melakukan tindakan atau perilaku berdasarkan penilaian pada tahap sebelumnya serta secara perlahan akan mengaplikasikan dalam kehidupannya. (4) Being (menjadi yang seperti yang diingikan). Pada tahap ini peserta didik sudah terbiasa dengan perilakuk yang telah dan sering dilakukan setiap harinya dan menjadi karakter yang permanen ${ }^{5}$. Karakter seseorang dipengaruhi oleh beberapa hal yakni pembawaan (nativisme), ingkungan (empirisme).

Dalam internalisasi karakter religius pada anak sekolah dasar diperlukan strategi yang tepat. Strategi adalah a plan, method, or series of activities designed to achieves a particular educational goal. Jadi, dengan demikian strategi dapat diartikan sebagai perencanaan yang berisi tentang rangkaian kegiatan yang didesain untuk mencapai tujuan pendidikan tertentu. Strategi menunjuk pada sebuah perencanaan untuk mencapai sesuatu. Sedangkan internalisasi adalah internalisasi merupakan proses menanamkan, memberikan pemahaman kepada seseorang tentang agama, sehingga dapat menyatu dan mendarah daging serta menjadi keyakinan dan kesadaran akan kebenaran agama yang dapat diwujudkan dalam sikap dan perilaku sehari-hari.

${ }^{5}$ Didik Efendi, "Proses Pembentukan Aqidah dan Akhlak Pada Siswa Sekolah Dasar di Kota Jayapura," AlAdzka: Jurnal Ilmiah Pendidikan Guru Madrasah Ibtidaiyah 9, no. 1 2019: 9. hlm. 16-18 
Sedangkan Internalisasi merupakan suatu proses yang berlangsung secara terus menerus dan diharapkan akan memiliki dampak masuknya sebuah nilai kedalam diri seseorang. Nilai yang masuk melalui proses internalisasi diharapkan akan mampu menjadi pedoman bagi individu dalam berperilaku ${ }^{6}$. Internalisasi dapat diartikan suatu proses yang berlangsung secara terus menerus yang akan memberikan dampak menyatukan nilai dalam diri seseorang, yang dipraktikkan dan berimplikasi pada sikap. Proses yang berlangsung secara terus menerus kepada peserta didik dapat memberikan dampak menyatunya nilai yang dipraktikkan dan berimplikasi pada peserta didik.

Dari uraian tersebut dapat disimpulkan bahwa strategi internalisasi karakter religius merupakan suatu cara untuk menanamkan nilai-nilai Islam kepada seseorang yang bertujuan untuk membentuk pola pikir tertentu yang digunakan dalam kehidupan nyata serta memfasilitasi, membimbing, mengembangkan nilai-nilai relegius pada anak sehingga menjadi pribadi yang berakhlak karimah. Strategi internalisasi karakter religius sangat efektif digunakan untuk menanamkan nilai-nilai karakter pada peserta didik di sekolah dasar.

Internalisasi karakter religius pada SDIT Qurrota A’yun Abepura Kota Jayapura hakikatnya merupakan penjelmaan dari pendalaman, pengamatan, dan mendalami karakter religius. Dalam hal ini seseorang dikatakan memiliki karakter religius apabila mampu mengamalkan nilai-nilai religius dalam kesehariannya baik di sekolah, keluarga maupun di lingkungan masyarakat. Untuk itu Lembaga Pendidikan SDIT Qurrata A'yun dalam menginternalisasikan nilai-nilai karakterter religius pada peserta didiknya melalui Islamic Culture (budaya islami).

Budaya Islam adalah cara hidup yang berkembang diwariskan dari generasi ke generasi umat Islam yang didasarkan kepada sumber nilai-nilai Islam. Nilai-nilai Islam sudah menjadi bagian yang tidak dapat dipisahkan dari budaya. Menurut saduddin Luqman dalam menerapkan budaya religious di lingungan pendidikan sama halnya dengan menciptakan sebuah lingkungan yang kondusif sebagai wadah untuk menanamkan nilai-nilai keislaman kepada peserta didik dengan metode pembiasaanpembiasaan yang baik. Peserta didik yang dibiasakan untuk melakukan kebaikan, akan terbiasa melakukan kebaikan ketika berada dalam komunitas sosial ${ }^{7}$.

Adapun Ruang lingkup dalam budaya religius menurut Saeful Anam, Muhammad Sidiq Jaelani dalam penelitiannya terdapat tiga hal, yakni (1) Perilaku. Perilaku dapat diartikan sebagai respon atau reaksi seseorang yang terlihat sikap, baik Gerakan badan atau ucapan. Dalam budaya sekolah yang Islami hal pertu menjadi perhatian adalah bagaimana pengaplikasian perilaku yang

\footnotetext{
${ }^{6}$ Wuri Wuryandani, dkk., "Internalisasi Nilai Karakter Disiplin melalui Penciptaan Iklim Kelas yang Kondusif di SD Muhammadiyah Sapen Yogyakarta”, Jurnal Pendidikan Karakter Tahun IV no. 2, Juni 2014: hlm. 177-178

${ }^{7}$ Asaduddin Luqman, "Pengembangan Karakter Melalui Pembiasaan Dan Keteladanan," Jurnal Pendidikan Islam Cendikia 12, no. 1 (2014)
} 
sesuai dengan nilai-nilai religius dalam pembudayaan tersebut. (2) Kebiasaan keseharian. Setting pembiasaan di sekolah merupakan strategi pendidikan yang bertujuan membentuk karakter kepada peserta didik. Dalam membentuk karakter peserta didik, hal yang perlu dirancang adalah bagaimana konsep dari startegi tersebut dapat melekat pada kepribadian mereka, yang nantinya dapat diaplikasikan dalam keseharian. (3) Simbol-simbol budaya. Simbol-simbol budaya Islami sejalan dengan ajaran dan nilai-nilai agama. Seperti dalam berpakaian, pemasangan motto yang mengandung pesan-pesan nilai agama. Simbol dalam budaya Islami akan mempengaruhi lingkungan sekitar dan memberi ciri khas pada sekolah ${ }^{8}$.

Internalisasi nilai-nilai karakter religius pada peserta didik di SDIT Qurrata A'yun melalui Islamic Culture mencangkup beberapa hal, yakni

\section{Pemberian Contoh (Keteladanan)}

Guru merupakan figur atau teladan bagi peserta didik. Peserta didik memiliki kecenderungan untuk mengikuti dan meniru hal-hal yang dilihat dan di dengarnya tanpa memikirkan dampak setelahnya. Oleh sebab itu guru harus memberikan contoh yang baik kepada peserta didik, sehingga peserta didik dapat menirukan hal-hal yang baik. Ada beberapa hal yang dicontohkan oleh guru seperti memberikan contoh kepada peserta didik saat melaksanakan sholat berjama'ah serta tepat waktu, puasa sunnah senin kamis, penggunaan jilbab, bertutur kata dan berperilaku yang baik, berwudhu, berdo'a, adab makan dan minum, serta program 3S (senyum, salam, dan sapa). Pemberian contoh yang diterapkan ini dapat ditiru oleh peserta didik dalam penanaman karakter peserta didik.

Pemberian contoh atau yang biasa disebut dengan keteladanan merupakan sikap yang ada dalam pendidikan Islam dan telah di praktikkan sejak zaman Rasulullah. Keteladanan ini memiliki nilai yang penting dalam pendidikan Islam, karena memperkenalkan perilaku yang baik melalui keteladanan, sama halnya memahami sistem nilai dalam bentuk nyata ${ }^{9}$. Dalam al-Qur'an keteladaan dijelaskan dalam Q.S al-ahzab ayat 21, Allah berfirman "Sesungguhnya telah ada pada (diri) Rasulullah itu suri teladan yang baik bagimu (yaitu) bagi orang yang mengharap (rahmat) Allah dan (kedatangan) hari kiamat dan dia banyak menyebut Allah".

\section{Peniruan (Imitasi)}

Sudut pandang teoritis Bandura dalam teori pembelajaran sosial yaitu: (1) Pembelajaran pada hakikatnya berlangsung melalui proses peniruan (imitation) atau pemodelan

\footnotetext{
${ }^{8}$ Saeful Anam, Muhammad Sidiq Jaelani “islamic school culture dan upaya menanamkan nilai-nilai religious di smp islamic qon gresik", Prosiding Annual Conference for Muslim Sclolars. Kopertais wilayah Surabaya 21-22 April 2018. hlm. 554-555 hlm. 59 .

${ }^{9}$ Syafi'i Ma'arif, Pemikiran Tentang Pembaharuan Islam di Indonesia (Yogyakarta: Tiara Wacana, 1991),
} 
(modeling); (2) Dalam imitation atau modeling individu dipahami sebagai pihak yang memainkan peran aktif dalam menentukan perilaku mana yang hendak ia tiru dan juga frekuensi serta intensitas peniruan yang hendak ia jalankan; (3) Imitation atau modeling adalah jenis pembelajaran perilaku tertentu yang dilakukan tanpa harus melalui pengalaman langsung; (4) Dalam imitation atau modeling terjadi penguatan tidak langsung pada perilaku tertentu yang sama efektifnya dengan penguatan langsung untuk memfasilitasi dan menghasilkan peniruan. Individu dalam penguatan tidak langsung perlu menyumbangkan komponen kognitif tertentu (seperti kemampuan mengingat dan mengulang) pada proses peniruan; (5) Mediasi internal sangat penting dalam pembelajaran, karena saat terjadi adanya masukan indrawi yang menjadi dasar pembelajaran dan perilaku dihasilkan, terdapat operasi internal yang mempengaruhi hasil akhirnya

\section{Pembiasaan}

Pembiasaan merupakan kegiatan yang dilakukan secara berulang-ulang dan konsisten. Menurut Muhammad Rasyid Dimas, pembiasaan adalah membiasakan anak untuk melakukan hal-hal tertentu sehingga menjadi kebiasaan yang mendarah daging, yang untuk melakukannya tidak perlu diarahkan lagi ${ }^{10}$. Sedangkan menurut Ramayulis metode pembiasaan adalah cara untuk menciptakan suatu kebiasaan atau tingkah laku tertentu bagi anak didik ${ }^{11}$. Bila dikaitkan dengan internalisasi karakter religius, pembiasaan merupakan cara yang dilakukan kepada peserta didik untuk bisa berfikir, berperilaku, bertutur kata, dan bertindak sesuai dengan islamic culture (budaya islami) serta nilai-nilai Islam.

Pembiasaan memiliki sifat yang berulang-ulang dimulai dari bangku kelas 1 hingga kelas 6 melalui pemberian contoh dan peniruan yang diterapkan di sekolah. Ada beberapa hal yang dibiasakan di SDIT Qurrota A'yun yakni (1) dibiasakan untuk melakukan 3S (senyum, salam, dan sapa) sehingga peserta didik terbiasa untuk memberikan salam dan menyapa orangorang yang ditemuinya. (2) dibiasakan disiplin. Peserta didik memiliki jadwal dalam kegiatannya pukul 07.00 wit, peserta didik dibiasakan berikrar saat berbaris diluar kelas. Pembiasaan sholat dhuha pun dilaksanakan pada pukul 07.15 wit sehingga peserta didik terbiasa untuk melaksanakan sholat sesuai waktu yang telah ditentukan, lalu setelahnya peserta didik terbiasa melafalkan asmaul husna dan berdo'a bersama-sama. Peserta didik pun terbiasa berdo'a sebelum dan sesudah melakukan kegiatan. (3) dibiasakan melakukan amalan sunah yang di contohkan nabi Muhammad SAW seperti Puasa sunnah senin kamis pun mulai terbiasa dilakukan oleh

\footnotetext{
2005), hlm. 47.

${ }^{11}$ Ramayulis, Metode Pendidikan Agama Islam (Jakarta: Kalam Mulia, 2005), hlm. 103.
}

${ }^{10}$ Muhammad Rasyid Dimas, 25 Kiat Mempengaruhi Jiwa dan Akal Anak (Bandung: Syamil Cipta Media, 
peserta didik mulai dari kelas 4 hingga kelas 6. (4) dibiasakan muroja'ah bersama dilapangan, dan juga setiap jum'atnya peserta didik melakukan sedekah jum'at sehingga menjadi kebiasaan untuk peserta didik.

\section{Praktik}

Praktik disebut sebagai suatu sikap seseorang yang telah mengetahui stimulus lalu diharapkan melaksanakan atau mempraktikkan tentang yang diketahui atau disikapinya (di nilai baik). Menurut Hamzah, belajar praktik adalah belajar keterampilan yang membutuhkan gerakkan motoik, pelaksanaan pembelajaran dilakukan di tempat kerja/lapangan ${ }^{12}$. Sedangkan menurut Sudjana, metode dalam pembelajaran yang digunakan dengan tujuan melatih serta meningkatkan kemampuan peserta didik dalam menerapkan pengetahuan dan keterampilan yang telah diperoleh untuk dilakukan di kehidupan nyata atau lapangan, pekerjaan, atau tugas yang sebenarnya ${ }^{13}$.

Strategi praktek ini tidak hanya dilakukan di sekolah saja tetapi juga dilakukan di rumah dengan pengawasan orang tua dan dilaporkan melalui buku penghubung. Dengan adanya pelaporan dari buku penghubung dapat diperoleh informasi tentang kegiatan peserta didik di rumah. Seperti saat sholat fardhu dan sholat dhuha tepat waktu, tilawah dilaksanakan atau tidaknya dapat dilihat dari buku penghubung, serta dapat mengetahui perilaku dan tutur kata peserta didik di rumah. Sehingga peserta didik tetap dapat mempraktikkan kembali di rumah seperti pembiasaan-pembiasaan yang diterapkan di sekolah. Dalam strategi ini dibutuhkan keja sam yang baik antara guru dan orang tua dengan cara memberikan informasi yang akurat tentang kebiasaan anaknya selama di rumah.

Dalam menerapkan strategi internalisasi karakter relegius pada peserta didik di SDIT Qurrata A'yun tentunya memiliki faktor pendukung dan penghambat. Adapun faktor pedukungnya terdiri dari:

\section{Lingkungan}

Lingkungan memiliki peran yang sangat mempengaruhi kehidupan manusia, karena lingkungan dapat mempengaruhi tingkah laku, pertumbuhan, dan perkembangan manusia. Menurut Emil Salim, lingkungan diartikan sebagai segala benda, kondisi, keadaan dan pengaruh yang terdapat dalam ruangan yang kita tempat dan mempengaruhi hal yang hidup termasuk kehidupan masyarakat ${ }^{14}$. Sedangkan menurut Hakim, lingkungan keluarga merupakan lingkungan utama dan

\footnotetext{
${ }^{12}$ Hamzah, Model Pembelajaran Menciptakan Proses Belajar Mengajar yang Kreatif dan Efektif (Jakarta: Bumi Aksara, 2008), h. 200.

${ }^{13}$ Sudjana, Metode dan Teknik Pembelajaran Partisipatif (Bandung: Falah Production, 2005), hlm. 157-158

${ }^{14}$ Emil Salim, Lingkungan Hidup dan Pembangunan (Jakarta: 1980), hlm. 16.
} 
pertama dalam menentukan keberhasilan belajar seseorang. Hal ini karena sebagian besar waktu seorang peserta didik berada di rumah. Dengan adanya hubungan yang harmonis di antara sesama anggota keluarga, tersedianya tempat dan peralatan belajar yang cukup memadai, keadaan ekonomi keluarga yang cukup, suasana lingkungan rumah yang tenang, adanya perhatian yang besar dari orang tua terhadap perkembangan proses belajar dan pendidikan anak-anaknya ${ }^{15}$.

Lingkungan keluarga dan lingkungan tempat tinggal memiliki keterkaitan yang sangat erat terkhusus internalisasi karakter religius ini. Lingkungan keluarga menjadi tempat belajarnya seseorang. Contohnya terhadap hafalan surahnya, ada anak yang hafalannya selalu bertambah, ada juga yang tidak. Dapat pula dilihat dari buku penghubung saat hari libur bahwa peserta didik tetap melaksanakan pembiasaan-pembiasaan disekolah saat ada di rumah. Lingkungan tempat tinggal yang memiliki mayoritas warga yang beragama Islam, lebih cenderung menjunjung nilai-nilai islami. Sedangkan lingkungan sekolah dapat dilihat dari kualitas guru serta latar belakang sekolah yang memiliki nuansa islami.

Orang tua berperan aktif dalam membimbing dan mengawasi peserta didik saat di rumah dan melaporkan kegiatan-kegiatan melalui foto atau buku penghubung, sedangkan tempat tinggal pun dapat menjadi faktor pendukung dalam cara bersikap dan bertutur kata yang baik, jika lingkungan tempat tinggalnya baik. Sekolah memiliki peran penting, dapat dilihat dari kualitas guru yang memiliki akhlak yang baik serta latar belakang sekolah yang memiliki nuansa islami.

\section{Partisipasi}

Partisipasi merupakan keterlibatan mental, emosi, dan psikis seseorang dalam memberikan respon terhadap kegiatan yang dilaksanakan serta mendukung mencapai sebuah tujuan dan bertanggung jawab atas keterlibatannya. Menurut Davis, partisipasi adalah keterlibatan mental dan emosional individu di dalam situasi berkelompok yang mendorong dia untuk berkontribusi terhadap tujuan kelompok dan mempertanggung jawabkan keterlibatannya ${ }^{16}$. Sedangkan menurut Sumaryadi, partisipasi adalah peran serta individu atau kelompok masyarakat dalam proses pembangunan baik dalam bentuk pernyataan maupun dalam bentuk kegiatan dengan memberi masukan sebagai berikut: (1) pikiran, (2) tenaga, (3) waktu, (4) keahlian (skill), (5) modal (materi), (6) ikut memanfaatkan dan menikmati hasil-hasil pembangunan ${ }^{17}$. Bentuk partisipasi sekolah dengan orang tua dilakukan melalui kerja sama membimbing dan mengawasi internalisasi karakter peserta didik, serta dalam bidang akademik yang dilaporkan melalui buku penghubung setiap harinya. Sedangkan partisipasi sekolah

\footnotetext{
${ }^{15}$ Hakim, Belajar Secara Efektif (Jakarta: Puspa Swara, 2005), hlm. 17.

${ }^{16}$ Keith Davis, Perilaku dalam Organisasi Edisi Ketujuh (Jakarta: Erlangga, 2000), hlm. 142.

${ }^{17}$ Sumaryadi, Efektivitas Implementasi Kebijakan Otonomi Daerah (Jakarta: Citra Utama, 2005), hlm. 46
} 
dengan masyarakat diterapkanlah kegiatan sedekah jum'at yang melibatkan peserta didik dalam membagikan sembako kepada masyarakat sekitar.

Sedangkan faktor penghambat dari strategi Internalisasi karakter relegius pada peserta didik di SDIT Qurrata A'yun sebagai berikut:

\section{Dukungan Sosial Yang Tidak Kondusif}

Dukungan adalah bentuk perhatian, penghargaan, semangat, penerimaan, maupun dalam bentuk lainnya yang berasal dari orang yang memiliki hubungan sosial yang dekat antara orang tua, saudara, anak, sahabat atau orang lain dengan tujuan membantu seseorang dalam mengalami sebuah permasalahan. Menurut Johnson, dukungan sosial merupakan keberadaan orang lain yang dapat diandalkan untuk memberi bantuan, semangat, penerimaan dan perhatian, sehingga bisa meningkatkan kesejahteraan hidup bagi individu yang bersangkutan ${ }^{18}$. Sedangkan menurut King, dukungan sosial adalah informasi atau umpan balik dari orang lain yang menunjukkan bahwa seseorang dicintai dan diperhatikan, dihargai, dan dihormati, dan dilibatkan dalam jaringan komunikasi dan kewajiban yang timbal balik ${ }^{19}$.

Namun jika dukungan sosial yang diperoleh peserta didik tidak kondusif, maka proses internalisasi karakter religius akan mengalami hambatan. Dukungan sosial yang tidak kondusif dapat berasal dari lingkungan tempat tinggal yang berada di pasar dan masyarakat yang kurang berpendidikan. Serta orang tua yang sibuk bekerja dapat menghambat internalisasi karakter religius peserta didik karena kurangnya bimbingan dan pengawasan terhadap anak. Misalnya ketika peserta didik memiliki orang tua yang sibuk bekerja, sehingga anak kurang mendapat bimbingan dan pengawasan dari orang tua. Salah satu contohnya saat diminta menambah muroja'ah orang tua tidak begitu membimbing dan juga orang tua tidak paham mengaji dengan menggunakan metode ummi, dapat menjadi penghambat dalam internalisasi karakter religius peserta didik.

Dengan demikian dukungan sosial merupakan suatu hal yang sangat dibutuhkan, karena setiap orang pasti membutuhkan keberadaan orang lain yang dapat di andalkan, yang dapat memberikan semangat, dan dilibatkan dalam komunikasi. Namun bila dukungan sosial yang tidak kondusif yang dihadapi oleh peserta didik, maka dapat menjadi penghambat dalam internalisasi karakter religius peserta didik. Karena peserta didik di usia sekolah dasar masih sangat membutuhkan keberadaan orang lain yang dapat diandalkan, membutuhkan semangat serta ada komunikasi yang baik.

\footnotetext{
${ }^{18}$ Johnson, Teori Sosiologi Klasik dan Modern (Jakarta: Gramedia, 1994), hlm. 472.

${ }^{19}$ King, Psikologi Umum (Sebuah Pandangan Apresiatif) (Jakarta: Salemba Humanika, 2012), hlm. 226.
} 
2. Karakteristik Peserta Didik

Setiap peserta didik memiliki karakteristik yang berbeda-beda. Kurangnya rasa percaya diri saat diminta menjadi imam sholat berjama'ah, tidak jujur dalam tindakan, perkataan dan perbuatan, serta tidak menaati aturan yang telah ditetapkan disekolah dapat menjadi penghambat dalam internalisasi karakter religius peserta didik. Kondisi ini dapat mempengaruhi proses internalisasi karakter religius peserta didik. Setiap orang memiliki karakteristik yang berasal dari tabiat, watak, pembawaan dan kebiasaan. Namun keseluruhan pola kelakukan dan kemampuan seseorang dapat dipengaruhi pula dari lingkungan sosial sehingga dapat menentukan pola perilaku serta aktivitas.

Setiap peserta didik di SDIT Qurrata A'yun memiliki karakter yang berbeda-beda yang menjadikan penghambat dalam internalisasi karakter religius seperti sikap kurang percaya diri, tidak menaati aturan, dan tidak jujur dalam tindakan, perkataan, maupun perbuatan dapat menjadi penghambat dalam internalisasi karakter religius. Karakter buruk seorang peserta didik pun dapat menjadi penghambat jika ditiru oleh peserta didik.

\section{SIMPULAN}

Kota Jayapura merupakan kota yang masarakatnya plural, berbagai agama, suku, budaya dan perpedaan-perbedaan lain ada di kota Jayapura. Hal ini apabila tidak dikelola dengan baik akan mempengaruhi karakter seseorang yang tinggal di kota Jayapura terutama anak usia sekolah dasar. Karakteristik anak usia sekolah dasar adalah suka meniru hal-hal yang disenanginya tanpa memperdulikan akibatnya. Lembaga Pendidikan terutama jenjang sekolah dasar harus mengambil peran dalam permasalahan ini. Salah satu sekolah dasar yang lingkungannya plural adalah Sekolah Dasar Islam Terpadu (SDIT) Qurrata A’yun. Salah satu strategi dalam Pendidikan karakter di SDIT Qurrata A'yun melalui Islamic Culture yang mencangkup beberapa hal, yakni (1) pemberian contoh (keteladanan), (2) peniruan (imitasi), (3) pembiasaan, (4) praktik. Adapun faktor yang mendukung keberhasilan internalisasi karakter religius peserta didik di SDIT Qurrota A'yun Abepura Kota Jayapura diantaranya yaitu Lingkungan dan Partisipasi. Sedangkan faktor yang menghambat adalah dukungan sosial yang tidak kondusif dan karakteristik peserta didik.

\section{DAFTAR PUSTAKA}

Davis, Keith Perilaku dalam Organisasi Edisi Ketujuh. Jakarta: Erlangga, 2000

Dimas, Muhammad Rasyid 25 Kiat Mempengaruhi Jiwa dan Akal Anak. Bandung: Syamil Cipta Media, 2005 
Efendi, Didik. "Proses Pembentukan Aqidah dan Akhlak Pada Siswa Sekolah Dasar di Kota Jayapura.” Al-Adzka: Jurnal Ilmiah Pendidikan Guru Madrasah Ibtidaiyah 9, no. 1 (2019): 9.

Efendi, Didik "Strategi Penanaman Karakter pada Anak Usia Sekolah Dasar di Kota Jayapura," Jurnal Elementaria Edukasia, Vol. 4, Nomor 1, 2021

Fathurrahman, Budaya Religius dalam Peningkatan Mutu Pendidikan, Tinjauan Teoritik dan Praktik Konstekstualisasi Pendidikan Agama di Sekolah.Yogyakarta: Kalimedia, 2015

Hakim, Belajar Secara Efektif . Jakarta: Puspa Swara, 2005

Hamzah, Model Pembelajaran Menciptakan Proses Belajar Mengajar yang Kreatif dan Efektif. Jakarta: Bumi Aksara, 2008

Johnson, Teori Sosiologi Klasik dan Modern. Jakarta: Gramedia, 1994

Kemendiknas, Pedoman Pelaksanaan Pendidikan Karakter. Jakarta: Kemendiknas, 2011

King, Psikologi Umum (Sebuah Pandangan Apresiatif). Jakarta: Salemba Humanika, 2012

Luqman, Asaduddin "Pengembangan Karakter Melalui Pembiasaan Dan Keteladanan," Jurnal Pendidikan Islam Cendikia 12, no. 1 (2014)

Ma'arif, Syafi'i Pemikiran Tentang Pembaharuan Islam di Indonesia .Yogyakarta: Tiara Wacana, 1991

Mustari, Mohamad Nilai Karakter Refleksi untuk Pendidikan. Jakarta: Rajawali Press, 2014

Ramayulis, Metode Pendidikan Agama Islam. Jakarta: Kalam Mulia, 2005

Saeful Anam, Muhammad Sidiq Jaelani “islamic school culture dan upaya menanamkan nilai-nilai religious di smp islamic qon gresik”, Prosiding Annual Conference for Muslim Sclolars. Kopertais wilayah Surabaya 21-22 April 2018

Salim, Emil Lingkungan Hidup dan Pembangunan. Jakarta: 1980

Sudjana, Metode dan Teknik Pembelajaran Partisipatif. Bandung: Falah Production, 2005

Sumaryadi, Efektivitas Implementasi Kebijakan Otonomi Daerah.Jakarta: Citra Utama, 2005

Wuryandani, Wuri dkk., "Internalisasi Nilai Karakter Disiplin melalui Penciptaan Iklim Kelas yang Kondusif di SD Muhammadiyah Sapen Yogyakarta", Jurnal Pendidikan Karakter Tahun IV no. 2, Juni 2014 